\title{
The History and Problems Faced by Independent Power Producers in Pakistan (1990-2015)
}

\author{
Yasir Arafat ${ }^{*}$, Naila Nazir ${ }^{2}$ and Jangraiz Khan ${ }^{3}$ \\ 'Department of Economics, University of Chitral, Khyber Pakhtunkhwa, Pakistan; yasir.eco@uoch.edu.pk \\ 2Department of Economics, University of Peshawar, Khyber Pakhtunkhwa, Pakistan; naila.uom@gmail.com \\ 3Elementary and Secondary Education, Peshawar, Khyber Pakhtunkhwa, Pakistan; economist95@hotmail.com
}

\begin{abstract}
Objectives: The present study discusses the history and challenges faced by Independent Power Producers (IPPs) in Pakistan from 1990 to 2015. For this purpose, data has been taken from IPPs yearly books, Private Power \& Infrastructure Board and National Electric Power Regularity Authority. The study is qualitative in nature, so descriptive analysis is used. Data are presented in the form of tables and figures and analyze by looking the policies adopted by government of Pakistan in different time periods and its impacts on the performance of IPPs. Methods/Findings: The study highlights the performance of IPPs rather than the whole energy sector of the economy. IPPs are contributing significant role to fulfill the requirements of energy needs all over the world particularly in Pakistan i.e. 30 percent of the overall energy production but no proper work have been done. The second different is that IPPs in their production, transmission and pricing is different from the regular energy sector that it totally deals with NEPRA rather than general public. So, this study is unique in a sense that it not only highlights the issues and problems faced by IPPs because of government policies but also because of their own internal problems. Application: The study concluded that IPPs are basically facing two main problems i.e. problem of scarcity of liquidity and high cost per production because most of the IPPs use furnace oil and diesel for their production, which is very much costly.
\end{abstract}

Keywords: Cost Per Production, Independent Power Producers (IPPs), Energy Production, Liquidity, Transmission

\section{Introduction}

The Independent Power Producers (IPPs) are Non-Utility Generators (NUGs) of electricity which are not owned by the public but which sell electricity to utilities or government. In case of Pakistan, the sole buyer of electricity from IPPs is Water and Power Development Authority (WAPDA). NUGs may Be privately-held facilities, cooperatives such as rural solar or wind Energy producers and non-energy Industrial concerns capable of feeding excess energy into the system ${ }^{1}$. So, it facilitates general public to fulfill the required demand of electricity in some extend and to reduce energy crisis in the country.

IPPs play an important role to overcome the energy shortage in Pakistan, but most of the IPPs produce below the actual capacity, as a result they face shortage of working capital, which is the outcome of great amount of receivable from Pakistan Electric Power Company (PEPCO).

Not only that the sole buyer of electricity from IPPs is WAPDA. They negotiate a tariff with the regularity authority National Electric Power Regulatory Authority (NEPRA) under a competitive bidding process. Most of the investors feel risk because of the tightly written, long term PPAs (Power Purchase Agreements) with underlay take or pay contract. IPPs are charged an "excessive fee». They found themselves in a impasse when they signed agreements and calculated expenses based on their costs, according to a huge tariff scheme. Whether or not, they took sufficient measures to quote correct costs to reduce the risk of the guaranteed profits ${ }^{2}$. 
In Pakistan, private power producers contribute about $30 \%$ in the total electricity generation capacity; the electricity market was opened to IPPs in 1990. Subsequently, 15 IPPs achieved commercial operations under Pakistan's first Power Policy 1994. Through Private Power and Infrastructure Board (PPIB), government of Pakistan employed four policies for private powers. The purpose of these polices was to invite more foreign and local investors to invest in this sector. The first power policy was employed in 1994 and then in 1995. The 1995 policy was adopted for hydro generation projects. After that, another policy was announced in 1998 and then in the year 2002. The Hub Power Project was the first IPP, which started its generation before the power policy announced by the government. Its total capacity was 1,291 MW and net capacity was 1200 MW. Under 1994 power policy agreement, 14 IPPs were entered into the generation activity and contribute $3,173 \mathrm{MW}$ of electricity in the national grid. About74 percent of electricity produced by these IPPs was based on furnace oil, which was so expensive and resulted into huge circular debt in the country ${ }^{3}$.

\section{The Salient Feature of Power Policy 1994}

The power policy of 1994 was an important step of government towards establishing of cooperation between private sectors to cope energy issue of the country. The first point of the agreement was about the selection of location, use of fuel and technology for the production of electricity. It was decided that investors are free to choice all these three factors on their own determination. Not only that, investor are free to choose investment on renewable, nonrenewable, wind, solar etc. projects but it was restricted to initiate any project on Indus river because of flood protection functions and water regulation.

The second agreement was took place on the determination of tariff for bulk purchase of power. It was decided that IPPs only sell power to WAPDA/KESC under long term contract. The government of Pakistan offers bulk power tariff of US cent $6.5 / \mathrm{kWh}$ and it is to be paid in Pakistani currency, as the average for first ten years for sale of electricity to WAPDA/KESC. The premium of US cents $0.25 / \mathrm{kWh}$ based on energy sold to WAPDA/KESC during the first 10 years of project operations, will also be allowed to the projects above $100 \mathrm{MW}$ which are commissioned under the scheme by end 1997 . This bulk power tariff were applied to all thermal projects and hydro proj- ects of up to $20 \mathrm{MW}$ and also all those projects which are based on non-renewable source of energy. The tariff was comprised of two components i.e. capacity price and energy price. The capacity price was the monthly basis payment which covered the debt servicing and the energy price was based on actual price of electricity sold by ${ }^{4}$.

Thirdly, the minimum requirement of investment was 20 percent of the total capital cost of the project. Government had established a Private Sector Energy Development Fund (PSEDF) with the assistance of USAID, World Bank and other multinational lending agencies, which are liable to provide 40 percent of total capital cost incurred in the project with the interest rate of 14 percent per annum for 23 years ${ }^{5}$.

All the power producers were exempted from corporate taxes and they were allowed to import technology and equipment without any custom duties and all other types of taxes. In this power policy long term purchase agreement took place between IPPs and the government, for a period of 15 to 30 years and government took the responsibility to purchase fuel for IPPs. The government also took the responsibility of the quality of fuel, in case of any other supplier.

Under this agreement, one window operation services was initiated for the project, which can facilitate the IPPs in negotiation with government, making decisions, monitoring according to the agreements made by them.

Under the terms of this agreement, National Power has assisted HUBCO in the review of designs for the plant and has undertaken to operate the plant to the requirements set by the Power Purchase Agreement with WAPDA. Under the power purchase agreement, WAPDA has to pay the fixed component of tariff irrespective of whether it used the electricity or not, and that HUBCO produces power to fill orders from WAPDA ${ }^{6}$.

\section{Policy Frame Work and Package of Incentive for IPPs in the Power Policy of 1995}

The 1995 hydel power policy is based on up-front tariff, announced by the government of Pakistan. Through this policy, the government was able to attracted private investment to over $3000 \mathrm{MW}$. In this policy frame, certain facilities and incentives were announced for IPPs to encourage investors. In this policy agreement, all the points of 1994 were remained same and few extra policies were included, which are explained as under: 
In this policy, it was declared that all the service charges have been worked out in dollar and are paid in dollar basis. All the power generation and transmission are declared as industry and all the companies can get benefit of incentives like that of other industries. Here, it is also important to mention that, the entire non-Muslim owners are exempted from zakat, on dividend. The transmission companies were also exempted from all kind of custom duties. Beside of all these incentives, the effect of this power policy was not up to mark because proper implementation was missing.

In 1997, the government publicly accused some IPPs, particularly HUBCO, of asking the government to sign misleading or inaccessible contracts. Although these processes did not matter, Pakistan's credibility was severely affected, and new foreign investment declined. A very important lesson is that the government should clarify and strengthen the dispute resolution mechanism for such contracts. First, the law governing this agreement was British law, but in all cases it was decided by Pakistani law. Secondly, although the IPP clearly indicates an agreement on the attraction of international arbitration, this promise has never been made in the country.

The government of Pakistan wants to make IPP able to compete on international markets. To this end, the government started restructuring the energy sector and privatized all generations of electricity. In its policy, the government privatizes the power transmission function and all WAPDA / KESC resources. In her policies, the government privatizes the power transmission functions and all the assets of WAPDA / KESC. A completely autonomous regulatory body was created under the name of National Electricity Regulatory Authority (NEPRA). All the policy related activities of IPPs were given to this authority.

All the eight areas of electricity boards of WAPDA/ KESC were restructured in eight public limited companies. Its eleven thermal states were restructured into a number of public limited companies but only its transmission system became a single public entity and all the transmission companies remain in public sector. WAPDA was reverted to its original role to maintain and supervise Dams, only ${ }^{\mathrm{Z}}$.

The NEPRA was formulated and approved from the parliament in 1997 and was given the status of an autonomous body which was responsible for maintenance of the energy sector. It can control the energy sector, guaranteeing the production, distribution and transmission of electricity. Tariff regulation was one of his responsibilities. After the restructuring of production, distribution and transfer of WAPDA / KESC power generation, NEPRA became completely authorized. All investments in the production, transmission and distribution of electricity are under the control of NEPRA. The 1998 policy was formulated under the control of NEPRA.

\section{Power Policy of 1998}

The 1994 private power policy and 1995, hydel policy framework was based on tariff announced up-front by the government and attracted private investment for over 3000 MW of capacity but the 1998 power policy proposed, was based on setting tariff based on competitive process through which private sector was invited and offered low tariff per kWh for delivering energy. the previous policies were formulated to invite more investors to invest on oil and gas power plants, which were basically comes from imports but in this policy government focused on to increase more investments on hydroelectric and indigenous coal resources in power generation. In the previous policies all the taxes on duties were eliminated from equipment manufacturers and engineering industry because they were new and imports were not easy for them, but in 1998 power policy all these inequities were eliminated.

\section{Salient Features of Power Policy 1998}

The selection of this project in this policy is based on the minimum rate through a competitive international tender. Various rates were allowed for this auction during the project. The selection criteria for this project are based on pre-qualification, evaluation and submission of proposals as well as on calls for proposals. This is not a feasibility study of the project site based on gas or coal, and no one has decided to accept the offer and invite it to the auction. The implementation of the Hydel Power project was built on the Build-Own-Operate-Transfer (BOOT) project and will be transferred to the province if a part has been selected for the project and all the projects in the field of thermal energy have been implemented on the basis of Build own operate (BOO).The rate will be adjusted based on the purchase price of the energy and the cost of the project. The government of Pakistan will follow the laws 
and regulations, as well as the agreement reached at the beginning of the project, and all companies will act in accordance with Pakistan's tax laws.

Companies are expected to operate in line with Pakistan's current fiscal laws $\stackrel{\underline{B}}{\text {. }}$

\section{Power Policy of 2002}

The important features of the power policy 2002 are presented below:

1. In the energy policy of 2002, the tariff rate was reduced to a minimum for all participants in the International Competitive Bidding (ICB) or was proposed as a starting point indicating a place where a feasibility study has not yet been carried out. Based on the Request For Proposal (RFP), the variable tariff was authorized for the entire duration of the project. The selection was based on offers and evaluation, prequalification and RFT issue.

2. In this policy framework, it was decided that without the feasibility report, competitive bid and offer for hydel and renewable resource based project is not allowed. So, for the above project proper feasibility report were made compulsory, and only the Letter Of Support (LOS) will be issued. The Letter Of Interest (LOI), will be issued only were feasibility study is reported through private or public sector only on raw side, approval will be made after complete study of report and bank guarantee.

3. The Hydel project is implemented on the basis of the BOOT project and the thermal projects are implemented by BOOT or BOO. The BOOT-based project will be transferred to the Government of Pakistan after the concession period.

4. The Energy Purchase Price (EPP) and the Purchase Price of Energy (CPP) were components of the tariff, and the CCP was $60-66 \%$ for hydro-power projects due to low PPE.

5. Government of Pakistan will guarantee all the terms written in the agreements from Implementation to supply of fuel supply.

6. All the IPPs are allowed to import equipment and machinery for thermal and hydel projects and all the companies were exempted from all kind of taxes.

7. The local engineering industry was encouraged to form joint venture to foreign companies to promote power sector.

\section{Power Policy 2015}

The salient futures of Power generation policy 2015 are given as under:

1. One window facilities are provided to IPPs for implementation in the area of AJK/ Gilgit-Baltistan.

2. All the taxes were exempted but only 5 percent duty was enforced on import of equipment, which has no manufacturing industry in Pakistan.

3. Government took guarantees obligation of provinces and purchaser of Power.

4. Government also protects IPPs from all kind of unexpected taxes and political interference.

5. Attractive ROE provided by the Regulator - Imported Coal: 27.3 ; Local Coal: 29.5; Thar Coal: 34.5; Hydro: 17\% IRR (23\% ROE) ; Gas/LNG: 15\% IRR (18\% ROE)

6. The rate will be based on the Pakistani whole price index (WPI) and the US consumer price index (CPI).

7. It makes the responsibility of government to convert other currency into Pakistani rupees ${ }^{9}$.

Table 1. Number of IPPs working with different power policies

\begin{tabular}{|l||l||l|l|}
\hline Power Policy & $\begin{array}{l}\text { Number } \\
\text { of } \\
\text { Projects }\end{array}$ & $\begin{array}{l}\text { Capacity } \\
\text { (MW) }\end{array}$ & $\begin{array}{l}\text { Total } \\
\text { Investment } \\
\text { (Million } \\
\text { US\$) }\end{array}$ \\
\hline $\begin{array}{l}\text { Project up to 1994 } \\
\text { Energy Policy }\end{array}$ & 1 & $1,292.00$ & $1,608.00$ \\
\hline $\begin{array}{l}\text { Under power } \\
\text { policy 1994, the } \\
\text { number of Project }\end{array}$ & 15 & $3,124.00$ & $3,490.00$ \\
\hline $\begin{array}{l}\text { Total number of } \\
\text { projects privatized }\end{array}$ & 1 & $1,638.00$ & $1,583.00$ \\
\hline $\begin{array}{l}\text { Project under 1995 } \\
\text { Hydel Policy }\end{array}$ & 1 & 84.00 & 215.00 \\
\hline $\begin{array}{l}\text { Total number of } \\
\text { Projects under } \\
\text { power policy 2002 }\end{array}$ & 13 & $2,934.00$ & $3,248.00$ \\
\hline Total & 31 & $9,072.00$ & $10,144.00$ \\
\hline
\end{tabular}

Source: Private Power and Infrastructure Board (PPIB)

All these policies were framed to invite more investor to invest in the electricity sector of the economy. Many analyst believes that all these policies were of high standard but their implementation were missing, the other reason of unsuccessful implementation of these policies were the frequently changing government. So far, 
the following IPPs are operating under different policy framework in Pakistan. The Tables 1-3 also shows their actual capacity and the total amount of investment on these IPPs.

Table 2. List of IPPs from 1990 to 2015

\begin{tabular}{|c|c|c|c|}
\hline Sl. No. & Project Names & $\begin{array}{l}\text { Gross } \\
\text { Capacity } \\
\text { (MW) }\end{array}$ & $\begin{array}{l}\text { Date of } \\
\text { Operation }\end{array}$ \\
\hline 1. & Uch Power Limited, Uch & 586.00 & Oct-2000 \\
\hline 2. & $\begin{array}{l}\text { AES Pak Gen. Pvt Limited, } \\
\text { Multan }\end{array}$ & 365.00 & Feb-98 \\
\hline 3. & $\begin{array}{l}\text { AES Lalpir Limited, } \\
\text { Multan }\end{array}$ & 362.00 & Nov-97 \\
\hline 4. & $\begin{array}{l}\text { Tapal Energy Limited, } \\
\text { Karachi }\end{array}$ & 126.00 & Jun-97 \\
\hline 5. & $\begin{array}{l}\text { Southern Electric Power } \\
\text { Limited, Lahore }\end{array}$ & 136.00 & Jul-99 \\
\hline 6. & $\begin{array}{l}\text { Saba Power Company } \\
\text { Limited, Lahore }\end{array}$ & 126.00 & Dec-99 \\
\hline 7. & $\begin{array}{l}\text { Rousch Power Limited, } \\
\text { Multan }\end{array}$ & 450.00 & Dec-99 \\
\hline 8. & $\begin{array}{l}\text { Liberty Power Project, } \\
\text { Faisalabad }\end{array}$ & 235.00 & Jan-11 \\
\hline 9. & $\begin{array}{l}\text { Kohinoor Energy Limited, } \\
\text { Lahore }\end{array}$ & 131.00 & Jun-97 \\
\hline 10. & $\begin{array}{l}\text { Japan power Generation } \\
\text { Pvt. Limited, Lahore }\end{array}$ & 135.00 & Jan-2000 \\
\hline 11. & $\begin{array}{l}\text { Habibullah Caostal Power } \\
\text { Pvt Co., Quetta }\end{array}$ & 140.00 & Sep-99 \\
\hline 12. & $\begin{array}{l}\text { Gul Ahmad Energy Ltd. } \\
\text { (GAEL), Karachi }\end{array}$ & 136.00 & Nov-96 \\
\hline 13. & $\begin{array}{l}\text { Fauji Kabirwala Power } \\
\text { Company, Multan }\end{array}$ & 157.00 & Oct-99 \\
\hline 14. & $\begin{array}{l}\text { Altern Energy Limited, } \\
\text { Attock }\end{array}$ & 29.00 & Jun-01 \\
\hline 15. & $\begin{array}{l}\text { New Bong Escape } \\
\text { Hydropower Project }\end{array}$ & 84.00 & Mar-13 \\
\hline 16. & KAPCO, Muzaffargarh & 1638.00 & Jun-96 \\
\hline 17. & Attock Gen, Rawalpindi & 165.00 & Mar-09 \\
\hline 18. & $\begin{array}{l}\text { Atlas Power Ltd., } \\
\text { Sheikhupura }\end{array}$ & 225.00 & Nov-09 \\
\hline 19. & Nishat Power Ltd., Lahore & 200.00 & Nov-09 \\
\hline 20. & Saif Power Ltd., Sahiwal & 229.00 & Apr-10 \\
\hline 21. & $\begin{array}{l}\text { Orient Power Ltd., Balloki, } \\
\text { Kasur }\end{array}$ & 229.00 & May-10 \\
\hline
\end{tabular}

\begin{tabular}{|c|c|c|c|}
\hline 22. & $\begin{array}{l}\text { NishatChunian Power } \\
\text { Ltd., Lahore }\end{array}$ & 200.00 & Jul-10 \\
\hline 23. & $\begin{array}{l}\text { Sapphire Electric Co. Ltd., } \\
\text { Muridke }\end{array}$ & 225.00 & Oct-10 \\
\hline 24. & $\begin{array}{l}\text { HUB Power Company } \\
\text { Limited, Narowal }\end{array}$ & 220.00 & Apr-11 \\
\hline 25. & $\begin{array}{l}\text { Halmore Power } \\
\text { Generation Co. Ltd., } \\
\text { Bhikki }\end{array}$ & 225.00 & Jun-11 \\
\hline 26. & $\begin{array}{l}\text { Davis Energen Power Ltd., } \\
\text { Jhang }\end{array}$ & 11.00 & Jul-13 \\
\hline 27. & Hub Power Project, Hub & 1292.00 & Mar-97 \\
\hline 28. & $\begin{array}{l}\text { Uch-II Power Limited, } \\
\text { Uch }\end{array}$ & 404.00 & Apr-14 \\
\hline 29. & $\begin{array}{l}\text { TNB Liberty Power Ltd., } \\
\text { Daharki }\end{array}$ & 235.00 & Jun-01 \\
\hline 30. & $\begin{array}{l}\text { EngroPowergenQadirpur } \\
\text { Ltd., Dakarki }\end{array}$ & 227.00 & Mar-10 \\
\hline 31. & $\begin{array}{l}\text { Foundation Power Co. } \\
\text { (Daharki) Ltd. }\end{array}$ & 185.00 & May-11 \\
\hline Total & & $9,108.00$ & - \\
\hline
\end{tabular}

Source: PPIB, WAPDA, and the World Bank

\section{Problems Faced by IPPs in Pakistan}

IPPs are considered an important entity to control the energy shortage in Pakistan but most IPPs are produced under current capacity, and therefore face a working capital deficit, which is the result of the surprising credits of the Pakistan Electricity Company (PEPCO). Not only is WAPDA the only buyer of electricity from IPPs. They are negotiating a tariff with the NAPRA (National Electricity Regulatory Authority) in a competitive bidding procedure. Most investors are at risk of long-term Power Purchase Agreements (PPAs) with contracts for the purchase or payment.IPP was charged with imposing excessive tariffs. Signing contracts and rate calculations have been blocked according to their cost for a very high rate plan. Regardless of whether they have taken sufficient steps to determine the correct costs for reducing the guaranteed profit risk. As noted above, the government should indicate political restrictions to prevent rent-seeking.

In 1997, the government destroyed its policy on certain IPPs, in particular for HUBCO, forcing it to further weaken by giving contracts. Due to disagreements between the IPPs and the government, most foreign 
Table 3. Portfolio for upcoming IPPs

\begin{tabular}{|c|c|c|c|c|c|c|c|c|}
\hline \multirow{2}{*}{ Year } & \multicolumn{2}{|l|}{ Hydel } & \multicolumn{2}{|l|}{ Coal } & \multicolumn{2}{|l|}{ Gas } & \multirow{2}{*}{$\begin{array}{l}\text { Total } \\
\text { (MW) }\end{array}$} & \multirow{2}{*}{$\begin{array}{l}\text { No. of } \\
\text { Projects }\end{array}$} \\
\hline & MW & No. & MW & No. & MW & No. & & \\
\hline 2017 & 150.0 & 1 & $2,970.0$ & 3 & 0 & 0 & $3,120.0$ & 4 \\
\hline 2018 & 0 & 0 & $2,640.0$ & 2 & 0 & 0 & $2,640.0$ & 2 \\
\hline 2019 & 232.0 & 2 & 1833.0 & 4 & 0 & 0 & $2,065.0$ & 6 \\
\hline 2020 & $1,360.0$ & 2 & 0 & 0 & 0 & 0 & $1,360.0$ & 2 \\
\hline 2021 & 870.0 & 1 & 0 & 0 & 0 & 0 & 870.0 & 1 \\
\hline 2022 & $2,033.0$ & 5 & 0 & 0 & 120.0 & 1 & $2,153.0$ & 6 \\
\hline 2023 & $1,690.0$ & 2 & 0 & 0 & 0 & 0 & $1,690.0$ & 2 \\
\hline 2024 & $1,088.0$ & 4 & 0 & 0 & 0 & 0 & $1,088.0$ & 4 \\
\hline 2025 & 80.0 & 1 & 0 & 0 & 0 & 0 & 80.0 & 1 \\
\hline Total & $7,503.0$ & 18 & $7,443.0$ & 9 & 120.0 & 1 & $15,066.0$ & 28 \\
\hline
\end{tabular}

Source: Power System Statistics - 40th Issue, 2014-15

investors feel insecure and reduce their investments in this sector. This competition does not allow both parties to agree accept to reduce foreign investment in this sector.

It was a great lesson for the government to take care while giving contract and signing any agreement. Clearly written contract and the formulation of strong dispute settlement mechanism were important. Firstly, all the laws governing in Pakistan was based on English law and decisions were made on the basis of Pakistani law. Secondly, the contract stated that IPPs may freely apply to international arbitration, but this obligation was never made by the state.

Due to these miss leading contracts, the dispute between IPPs and the government became worse. In 1999, WAPDA sued HUBCO to keep HUBCO from international arbitration to resolve the dispute. The Court ruled in favor of WAPDA and issued an ex parte decision, limiting HUBCO to address international arbitration ${ }^{10}$. The decision was appealed at the same time as the Supreme Court, but the court retained its ruling, as the Supreme Court decided to limit HUBCO to resorting to an international arbitration agreement to resolve a tariff dispute with WAPDA $\underline{11}$.

The purpose of this study is not to discuss the dispute between IPPs and WAPDA but here it is matter of concern that how the efficiency and productivity of IPPs were effected due to bad policies of government and unspecified contract between these two parties. This whole dispute not only discourages the performance of local
IPPs but also effect the image of Pakistan among the foreign investors. The case was poorly handled by the court and the dispute remains dispute till 2000. During these three years, most of the investors lost their confident on investing on this particular sector of the economy. This was obviously a big shock for a country like Pakistan which was facing a huge energy shortfall at that time.

The energy issue is still a priority for the government. The government intends to meet its obligations, aware that good governance and regulation will contribute to creating a sustainable, affordable and reliable energy system (Fraser, 2005).The government is sincerely committed to adding 10,400 megawatts of electricity to Pakistan's national grid by 2017-18, along with reduced production costs and transmission losses. In accordance with the 2025 concept, the government is committed to producing 45,000 MW of electricity, offering uninterrupted, economical and clean energy for everyone. Therefore, the government encourages private investment to achieve a combination of energy production by developing local energy resources, especially gas, and coal, shale gas, etc., in order to reduce load shedding along with reduction electricity bills.

IPP Basically Faces Two Major Problems, which are as under:

1. The IPP is mainly confronted with a "shortage" (shortterm liquidity) problem. A number (proposals were submitted by an independent power producers 's advi- 
sory council to in order resolving issues, including the allocation of limits working capital.

2. Because IPPs can purchase furnace oil and diesel from the Pakistani State Oil (PSO) for power generation, it has become extremely difficult for them due to lack of working capital.PSO itself is responsible for circular debt, which can purchase oil from domestic refineries and also responsible to supply it to IPPs and other state-owned thermal electricity generation companies $\underline{12}$.

\section{Conclusion}

By analyzing different data and structural improvements in IPPs, it is concluded that government tin some extend has played an important role to encourage the private investors to invest in this particular sector of the economy. During the emergency situation of the IPPs in Pakistan, the energy situation was very sensitive; the Pakistani government needed appropriate energy and policy reforms to encourage Independent Power Producers to do their part to overcome the country's energy needs. As a result, more IPPs started their operation and contributed more in the national economy. But the main problem was that most of them was hydel in nature and was restricted to supply energy only to WAPDA, the time was not favorable both for IPPs and government because the country was already facing high energy shortfall and WAPDA was not in a position to pay their outstanding in proper time. It created lot of losses to IPPs and resulted in huge circular debt in the economy. The second problem was that, although these power policies were remarkable for IPPs but proper implementation was missing. For example, in the 1994 power policy, all non-Muslim owners of intellectual property rights have been completely excluded from all types of zakat in the form of dividends, but this policy has not been properly implemented and highly discouraged for owners. In 1997, IPPs control was transferred from WAPDA to NEPRA and has received an autonomous status, which were given an authority to deal with all kind of licensing, it was observed that proper license were not issued to the competent investors. In 1998 power policy, low tariff was offered to investors and government want to shift IPPs from hyrel to hydroelectric and indigenous coal resources but the policy were not up to mark.
Not only was that, taxes on duties were also eliminated from equipment which results in huge losses for the government, who was already facing fatalities in this sector.

Therefore, it is concluded that the discouraging and low productivity of IPPs in Pakistan is just because of poor policies and unfair contracts of the government. Taking into account past mistakes is the key to formulating this policy. Only the privatization of the sectors of thermal power, while at the same time supporting energy production on a large scale, and transport activities are not a complete solution. Privatization for one reason or another is considered as a panacea for all diseases caused by international donor organizations, and will invariably manifest itself in the policies.

\section{References}

1. Energy Dictionary. Date accessed: 2016. www.dictionary. com/browse/energy.

2. An overview of electricity sector in Pakistan: Islamabad Chamber of Commerce and Industry Asia. Springer International Publishing; 2014. p. 117-43.

3. National Electric and Power Regulatory Authority. Date accessed: 31/10/2018. https://en.wikipedia.org/wiki/ National_Electric_Power_Regulatory_Authority.

4. Siddiqui, A. IPPs: The Real Issue, The Pakistan Development Review. 1998; 37(4):811-82. https://doi.org/10.30541/ v37i4IIpp.811-823.

5. Yearly Book. Date accessed: 2019. http://uhl-mi.org/yearbooks.html.

6. Private Power and Infrastructure Board. Date accessed: 2003. www.ppib.gov.pk.

7. Power Policy. Date accessed: 1995. https://www.gktoday.in/ gk/mega-power-policy-1995/.

8. Power Policy. Date accessed: 1998. https://powermin.nic. in/en/content/policy-hydro-power-development.

9. Power Policy. Date accessed: 2005. http://www. economicsdiscussion.net/india/power-crisis/power-policies-formulated-by-government-of-india/20957.

10. Khan MA, Ahmad U. Energy Demand in Pakistan: A Disaggregate Analysis, The Pakistan Development Review. 2007; 47:437-55. https://doi.org/10.30541/ v47i4IIpp.437-455.

11. Shah MA. Private sector investment in the energy sector: case of Pakistan, NIPA Journal. 2002; 7(2):11-32.

12. Pakistan's energy mix: Power and politics. Date accessed: 04/10/2015. http://www.dawn.com/news/1210831. 